\title{
PENINGKATAN HASIL BELAJAR PESERTA DIDIK MELALUI PENERAPAN MODEL PEMBELAJARAN BERBASIS MASALAH PADA SISWA SMK NEGERI 1 SAKRA UNTUK MATERI PROGRAM LINIER
}

\author{
Wakqoatil Wakiah \\ SMK Negeri 1 Sakra, Lombok Timur, Nusa Tenggara Barat, Indonesia \\ Email: w.wakiah@gmail.com
}

Diterima: 02 November 2019, Disetujui: 20 November 2019, Dipublikasikan: 30 November 2019

\begin{abstract}
Abstrak: Penelitian tindakan kelas ini bertujuan menigkatkan hasil belajar siswa melalui penerapan model pembelajaran berbasis masalah pada kelas X SMK Negeri 1 Sakra, Lombok Timur, Nusa Tenggara Barat. Penelitian Tindakan Kelas yang dilaksanakan pada tahun ajaran 2017/2018 dimana penelitian ini menggunakan tiga siklus yang menggunakan sampel peserta didik sebanyak 30 orang. Indikator keberhasilan penelitian ini adalah jumlah peserta didik yang tuntas minimal $75 \%$ dengan KKM sebesar 75. Tahapan setiap siklus peneltian ini adalah pertama kegiatan awal, guru menyampaikan tujuan pembelajaran. Kemudian dilanjutkan pembagian kelompok belajar siswa dalam mengerjakan Lembar Kerja pada kegiatan inti. Guru menginformasikan bahwa akan ada penghargaan diakhir pembelajaran bagi siswa yang aktif selama proses pembelajaran. Kemudian siswa diberikan apersepsi. Kedua, guru memberikan masalah yang berkaitan dengan kehidupan nyata dan mengaitkan dengan materi yang akan dipelajari untuk memancing pesreta didik untuk berpikir. Ketiga, kegiatan penutup yang berisi refleksi pembelajaran dengan proses tanya jawab dan guru dapat menunjuk peserta jika tidak ada yang angkat tangan. Selanjutnya guru memberikan kesimpulan dan memberikan kuis serta memberikan informasi tentang kegiatan pembelajaran yang dilakukan pada pertemuan berikutnya. Hasil belajar peserta didik dapat dilihat pada siklus I mencapai nilai rata-rata 60,50. Pada siklus II nilai peserta didik mencapai nilai rata-rata 73,90. Dan pada siklus III nilai peserta didik mencapai nilai rata-rata 85,60. Berdasarkan hasil ini dapat disimpulkan bahwa penerapan model pembelajaran berbasis masalah pada materi program linier efektif dilakukan guna meningkatkan hasil belajar peserta didik.
\end{abstract}

Kata kunci: Model Pembelajaran Berbasis Masalah, Pemahaman Peserta Didik, PTK.

\section{PENDAHULUAN}

Pembelajaran matematika memiliki tantangan tersendiri. Matematika memiliki kedudukan penting dalam Pendidikan karena menjadi salah satubidang studi di sekolah yang harus dikuasaioleh peserta didik mulai jenjang sekolah dasar hingga Pendidikan lanjut di perguruan tinggi. Matematika merupakan sarana komunikasi sains tentang pola-pola yang berguna untuk melatih berfikir logis, kritis, kreatif dan inovatif dan memberi banyak bantuan dalam berbagai disiplin ilmu yang lain. Oleh karena itu maka dapat dikatakan bahwa setiap orang memerlukan pengetahuan matematika untuk membekali diri dengan kemampuan berpikir logis, analitis, sistematis, kritis, dan kreatif, serta kemampuan bekerjasama (Shadiq, 2009). Dalam pembelajaran matematika banyak model pembelajaran yang dapat diterapkan. Misalnya pembelajaran berbasis masalah adalah suatu model pembelajaran yang menggunakan masalah dunia nyata sebagai suatu konteks bagi siswa untuk belajar tentang cara berfikir kritis dan keterampilan pemecahan masalah, serta untuk memperoleh pengetahuan dan konsep yang esensial dari materi pelajaran (Sumartini, 2016). Model pembelajaran berbasis masalah merupakan suatu model pembelajaran aktif yang berdasarkan pada penggunaan masalah terstuktur sebagai rangsangan pembelajaran. Peran guru dalam model pembelajaran berbasis masalah adalah menyajikan masalah,mengajukan pertanyaan, dan memfasilitasi penyelidikan dan dialog 
(Rahman, 2018; Santyasa, 2007). Pembelajaran berbasis masalah melibatkan siswa untuk memecahkan masalah melalui tahap-tahap metode ilmiah sehingga siswa dapat mempelajari pengetahuan yang berhubungan dengan masalah tersebut dan sekaligus memiliki keterampilan untuk memecahkan masalah (Bandi, 2015).

Berdasarkan pengamatan guru di kelas XI SMKN 1 Sakra Lombok Timur, Nusa Tenggara Barat pada materi program linier, terdapat berberapa masalah dalam proses pembelajaran. Pertama, pembelajaran konvensional yang kami terapkan sebelumnya tidak menarik bagi peserta didik, mereka terlihat bosan dan cepat mengantuk. Peserta didik tidak dapat mengikuti pembelajaran dengan konsentrasi tinggi, mereka ribut pada saat kegiatan belajar mengjar berlangsung, peserta didik juga mengobrol dengan teman sebangku dan seringkali tidak mengerjakan tugas. Kedua, peserta didik terlihat pasif, kurang konsentrasi dan kurang aktif dalam kegiatan belajar, kemudian peserta didik malu bertanya menyangkut materi yang diajarkan, bila guru bertanya peserta didik pun tidak menjawab. Hal ini menyebabkan banyak peserta didik kesulitan mencapai KKM pada mata pelajaran matematika.

Berdasarkan masalah yang kami temukan tersebut maka kami menerapkan solusi yaitu model pembelajaran berbasis masalah. Pemilihan pembelajaran berbasis masalah karena dapat meningkatkan pemahaman siswa dan hasil belajar. Ini sesuai dengan publikasi banyak penelitian dari guru guru sebelumnya (Husna, 2017; Sumartini, 2017). Maka dari itu melalui penggunaan pembelajaran berbasis masalah ini diharapkan peserta didik mampu meningkatkan pemahaman peserta didik terhadap pembelajaran matematika pada materi program linier. Berdasarkan latar belakang masalah tersebut di atas, maka telah dilakukan Penelitian Tindakan Kelas dengan melakukan tiga siklus dengan penerapan model pembelajaran berbasis masalah dalam upaya peningkatan hasil belajar siswa di kelas XI SMKN 1 Sakra Lombok Timur, Nusa Tenggara Barat pada program linier.

\section{METODE}

Metode penelitian ini adalah penelitian tindakan kelas dengan penerapan model pembelajaran berbasis masalah sebagai upaya meningkatkan pemahaman peserta didik pada materi program linier. Penelitian ini dimulai dari bulan September 2017 sampai dengan Februari 2018. Langkah-langkah penelitian yang dilakukan terbagi ke dalam bentuk siklus dimana setiap siklus terdiri dari empat kegiatan. Siklus pertama, siklus kedua, maupun siklus ketiga dalam PTK ini terdiri dari perencanaan, pelaksanaan, pengamatan dan refleksi. Data hasil belajar dikumpulkan untuk setiap siklus. Adapun teknik pengumpulan data yang digunakan untuk mendapatkan data penelitian dengan cara tes, wawancara, observasi dan studi dokumentasi. Subjek penelitian adalah peserta didik sebanyak 30 orang. Indikator keberhasilan penelitian ini adalah jumlah peserta didik yang tuntas minimal $75 \%$ dengan KKM sebesar 75. Tahapan setiap siklus peneltian ini adalah pertama kegiatan awal, guru menyampaikan tujuan pembelajaran. Kemudian dilanjutkan pembagian kelompok belajar siswa dalam mengerjakan Lembar Kerja pada kegiatan inti. Guru menginformasikan bahwa akan ada penghargaan diakhir pembelajaran bagi siswa yang aktif selama proses pembelajaran. Kemudian siswa diberikan apersepsi. Kedua, guru memberikan masalah yang berkaitan dengan kehidupan nyata dan mengaitkan dengan materi yang akan dipelajari untuk memancing pesreta didik untuk berpikir. Ketiga, kegiatan penutup yang berisi refleksi pembelajaran dengan proses tanya jawab dan guru dapat menunjuk peserta jika tidak ada yang angkat tangan. Selanjutnya guru memberikan kesimpulan dan memberikan kuis serta memberikan informasi tentang kegiatan pembelajaran yang dilakukan pada pertemuan berikutnya

\section{HASIL DAN PEMBAHASAN}

Tabel 1 dan gambar 1 menunjukkan bahwa upaya meningkatkan pemahaman peserta didik pada materi program linier melalui model pembelajaran berbasis masalah lebih mudah dipahami bagi peserta didik kelas peserta didik kelas XI di SMKN 1 Sakra Lombok Timur, Nusa Tenggara Barat. Model pembelajaran berbasis masalah diterapkan pada Penelitian Tindakan Kelas pada pembelajaran metamtika kelas X di SMKN 1 Sakra Lombok Timur, Nusa Tenggara Barat pada materi program linier. Penelitian ini mengambil data dan menyimpulkan data yang diperoleh dengan membahas hasil test evaluasi, hasil observasi, wawancara, catatan lapangan dan refleksi dari 
variabel peneliti. Hasil belajar adalah variable terikat yang diujikan pada penelitian ini, dimana peserta didik mengalami perlakukan siklus pembelajaran dan hasil siklus dan hasil observasi kegiatan belajar mengajar. Pada setiap siklus dilakukan perbaikan penelitian tindakan yang dilakukan, upaya ini terus dilakukan hingga semua siswa mencapai ketuntasan maksimal.

Tabel 1. Rekapitulasi Hasil Belajar Peserta Didik Siklus I, II dan III

\begin{tabular}{lccc}
\hline \multicolumn{1}{c}{ Kriteria } & Siklus I & Siklus II & Siklus III \\
\hline Jumlah nilai & 1530 & 1710 & 1845 \\
Rata-rata ketercapaian & 60,50 & 73,90 & 85,60 \\
Jumlah peserta didik tuntas & 12 & 23 & 30 \\
Jumlah peserta didik tidak tuntas & 18 & 7 & 0 \\
Jumlah peserta didik tuntas (\%) & $40 \%$ & $76 \%$ & $100 \%$ \\
Jumlah peserta didik tidak tuntas (\%) & $60 \%$ & $14 \%$ & 0 \\
\hline
\end{tabular}

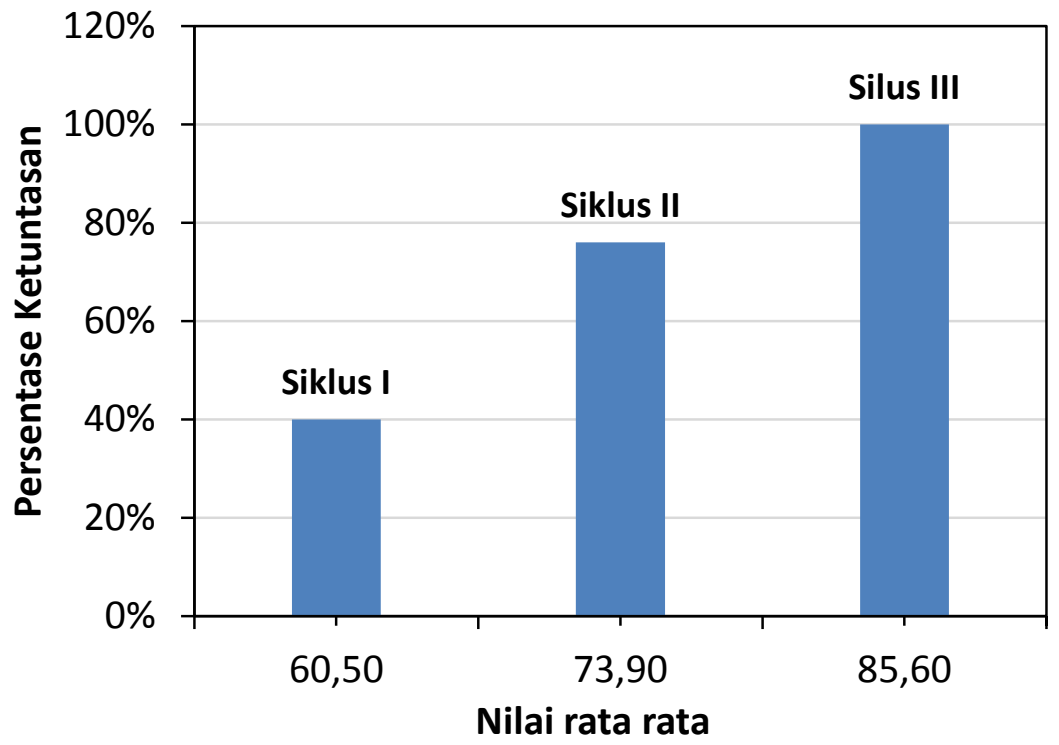

Gambar 1. Rekapitulasi Hasil Belajar Peserta Didik Siklus I, II dan III dengan presentase ketuntasan.

Pemahaman peserta didik belum tampak dimana peserta didik masih terlihat tidak aktif dan suasana dalam kelas tidak kondusif pada tahapan siklus I. M odel yang diterapkan merupakan model baru sehingga peserta didik belum terbiasa dan belum paham terhadap tugas yang harus dikerjakan akibatnya suasana kelas menjadi ribut. Pada siklus ini, kolabolator ahli memberikan masukan kepada peneliti agar memberikan penjelasan materi dengan lebih menarik dan diberikan secara ringan agar tercapainya hasil belajar yang cukup baik pada tahapan berikutnya.

Selnjutnya pada tahapan siklus II sebenarnya peserta didik sudah mencapai indikator ketuntasan yang diharapkan sebesar $76 \%$. Namun ketuntasan ini masih sedikit di atas harapan, sehingga kami melanjutkan ke siklus III. Pada sikulus II sudah mulai adanya tampak peningkatan pembelajaran dengan menggunakan metode koperatif. Hal ini dapat dilihat dari Tabel 1 dimana terjadi peningkatan hasil belajar. Terlihat kegiatan peserta didik mulai kondusif pada siklus II dan banyak peserta didik yang memperhatikan pembelajaran yangcukup baik karena adanya antusian peserta didik dalam menerima pembelajaran. Pada siklus ini kolabolator menyarankan agar peneliti lebih fokus pada beberapa peserta didik yang belum bermasalah. Hal in perlu dilakukan agar semua peserta didik menjadi fokus dan berkonsentrasi pada pembelajaran yang dilakukan.

Perubahan yang sangat baik pada siklus 
III. Peserta didik mulai penyelesaian tugas tugas yang diberikan dan terlihat peserta didik mulai aktif dalam mengikuti diskusi kelompok yang dilakukan. Tidak terlihat dominasi individu yang terlalu berlebihan pada satu kelompok. Secara umum tampak bahwa hasil belajar mengalami peningkatan pada setiap siklusnya. Hasil ini selaras dengan beberapa penelitian sebelumnya (Sulasti, 2013; Kurnia, 2013). Berdasarkan hasil pengamatan atau observasi, dokumentasi dan pelaksanaan setiap siklus menunjukan bahawa penelitian tindakan kelas dengan penerapan model pembelajaran berbasis masalah dapat memberikan hasil sesuai yang diharapkan terhadap peningkatan pemahaman peserta didik kelas.

\section{KESIMPULAN}

Penelitian tindakan kelas yang telah dilakukan dengan penerapan model pembelajaran berbasis masalah pada pembelajaran metematika materi Program linier di kelas X di SMKN 1 Sakra Lombok Timur, Nusa Tenggara Barat menunjukkan hasil yang baik. Hasil belajar peserta didik pada setiap siklus pembelajaran mengalami peningkatan. Pada siklus II telah tercapai ketuntasan yang diharapkan, namun berdasarkan hasil diskusi dengan vasilitator akhirnya kami penelitian diujikan untuk sampai tahap siklus III. Pada siklus III, suasana belajar mulai meningkat kondusif, siswa lebih aktif, adanya motivasi, dan peserta didik lebih berani dalam bertanya maupun menjawab pertanyaan yang diberikan oleh guru dalam proses pembelajaran. Berdasarkan hasil ini maka kesimpulan yang kami buat adalah penerapan model pembelajaran berbasis masalah mampu meningkatkan pemahaman siswa pada materi program linier.

\section{REFERENSI}

Husna, H. (2017). Meningkatkan Hasil Belajar Matematika Dengan Penerapan Model Problem Based Learning Pada Materi Program Linier Siswa. Jurnal Serambi Ilmu, 18(2).

Rahman, T. (2018). Aplikasi model-model pembelajaran dalam penelitian tindakan kelas. CV. Pilar Nusantara.

Santyasa, I. W. (2007). Model-model pembelajaran inovatif. Universitas Pendidikan Ganesha.

Shadiq, F. (2009). Model-model pembelajaran matematika SMP. Yogyakarta: P4TK Matematika Depdiknas.

Sumartini, T. S. (2016). Peningkatan kemampuan pemecahan masalah matematis siswa melalui pembelajaran berbasis masalah. Mosharafa: Jurnal Pendidikan Matematika, 5(2), 148-158. Bandi, N. T. L. (2015). Pengaruh Model Pembelajaran Berbasis Masalah Terhadap Hasil Belajar Matematika Siswa Kelas VIII SMP Negeri 12 Kendari. Jurnal Penelitian Pendidikan Matematika, 3(3), 69-82.

Sumartini, T. S. (2016). Peningkatan kemampuan pemecahan masalah matematis siswa melalui pembelajaran berbasis masalah. Mosharafa: Jurnal Pendidikan Matematika, 5(2), 148-158. 